\title{
A NOTE ON THE RACKETEERING, BANK ROBBERY, AND "KICK-BACK" LAWS
}

Racketeering-the systematic extortion of money from commercial enterprises by violence or intimidation-is a phenomenon confined in the main to trades and industries in which the individual units are small and highly competitive, and are lacking therefore in the resources to resist their oppressors. Hence the racketeers' operations are usually localized, but in recent years they have occasionally invaded industries handling products moving in interstate commerce. In such instances, when the federal government could marshal sufficient evidence of a combination or conspiracy to restrain such commerce, proceedings were initiated under the Sherman Anti-Trust Act against the racketeers and their industrial or labor allies. ${ }^{1}$

Although such prosecutions were generally successful, they revealed the weaknesses of this Act as a means of repressing racketeering. In a memorandum prepared by the Department of Justice setting forth the need for additional legislation, the shortcomings of the Sherman Act in this respect were described as follows:

This act ... was designed primarily to prevent and punish capitalistic combinations and monopolies, and because of the many limitations engrafted upon the act by interpretations of the courts, the act is not well suited for prosecution of persons who commit acts of violence, intimidation, and extortion. Furthermore, the Sherman Act requires proof of a conspiracy, combination, or monopoly, and it is often difficult to prove that the acts of racketeers affecting interstate commerce amount to a conspiracy in restraint of such com-

\footnotetext{
${ }^{2}$ The activities of the federal government against racketeering prevalent in the live poultry trade in the New York metropolitan area furnish a good illustration of such proceedings. This poultry is shipped almost exclusively from midwestern states to commission men in New York who dispose of it to marketmen who in turn slaughter and distribute it to retailers. A combination of marketmen and leaders of the truckmen's and butchers' unions succeeded in allocating retailers among the marketmen, levying one cent per pound on each marketman's sales. The recalcitrant marketman was prevented from purchasing from commission men, union members refusing to drive his trucks or slaughter his poultry. Ninety defendants were indicted in 1929 for thus violating the Sherman Act; 61 were convicted and their convictions affirmed on appeal. Greater New York Live Poultry C. of C. v. U. S., 47 F. (2d) 156 (C. C. A. 2d 193r). Nevertheless, the conspiracy continued. Injunction proceedings were then brought under the Act against ror defendants, charging a conspiracy to restrain trade. A sweeping decree was granted which was carried in appeal to the United States Supreme Court and there affirmed. Local 167 , etc. v. U. S., 291 U. S. 293, 54 Sup. Ct. 396 (1934). In the interim contempt proceedings had been begun against seven defendants who, as delegates of two labor unions, had coerced marketmen to buy feed from one company at prices 50 per cent above the market level and to rent coops at exorbitant prices. Five were convicted, and their appeals are now pending. Although these prosecutions have done much to eliminate racketecring from the industry, it was still found desirable to insert an anti-racketeering section (art. viI, \$2I) in the industry's Code of Fair Competition.
} 
merce, or a monopoly. Moreover, a violation of the Sherman Act is merely a misdemeanor, punishable by I year in jail plus $\$ 5,000$ fine, which is not a sufficient penalty for the usual acts of violence and intimidation affecting interstate commerce. ${ }^{2}$

A bill ${ }^{3}$ aimed directly at racketeering was introduced by Senator Copeland in the Senate on January II, I934. In the course of its consideration opposition was manifested by representatives of organized labor who argued that its prohibitions were so sweeping that they might be invoked by prosecuring officials hostile to labor to suppress strikes for higher wages. This objection posed a difficult problem of draftsmanship, for in a number of instances racketeers, gaining control of union organizations, had abused their authority for personal gain. It was difficult to devise a shield for the legitimate activities of labor which would not protect them. Eventually, however, sufficient safeguards were inserted in the bill to induce the withdrawal of labor opposition. Thereupon, the bill was passed and became law June I8, 1934. ${ }^{4}$

The Act, the text of which is set forth below, ${ }^{5}$ makes it a felony, punishable by

${ }^{3}$ Quoted in S. Rep. No. 532 to accompany S. 2248, 73rd Cong., 2nd Sess. (1934).

${ }^{3}$ S. 2248, 73rd Cong., 2nd Sess. (I934). For the text of this bill, see 78 Cong. Rec. 435 (I934).

"Public, No. 376, 73rd Cong., 2nd Sess. (1934), I8 U. S. C. $\Lambda$. (Supp. 1934) $\$ \$ 421-425$.

'An Act to protect trade and commerce against interference by violence, threats, coercion, or intimidation. Be it enacted, etc., That the term "trade or commerce," as used herein, is defined to mean trade or commerce between any States, with foreign nations, in the District of Columbia, in any Territory of the United States, between any such Territory or the District of Columbia and State or other Territory, and all other trade or commerce over which the United States has constitutional jurisdiction.

SEC. 2. Any person who, in connection with or in relation to any act in any way or in any degrec affecting trade or commerce or any article or commodity moving or about to move in trade or commerce-

(a) Obtains or attempts to obtain, by the use of or attempt to use or threat to use force, violence, or coercion, the payment of money or other valuable considerations, or the purchase or rental of property or protective services, not including, however, the payment of wages by a bona-fide employer to a bonafide employee; or

(b) Obtains the property of another, with his consent, induced by wrongful use of force or fear, or under color of official right; or

(c) Commits or threatens to commit an act of physical violence or physical injury to a person or property in furtherance of a plan or purpose to violate sections (a) or (b); or

(d) Conspires or acts concertedly with any other person or persons to commit any of the forcgoing acts; shall, upon conviction thereof, be guilty of a felony and shall be punished by imprisonment from one to ten years or by a fine of $\$ 10,000$, or both.

SEc. 3. (a) As used in this Act the term "wrongful" means in violation of the criminal laws of the United States or of any State or Territory.

(b) The terms "property," "moncy," or "valuable considerations" used hercin shall not be decmed to include wages paid by a bona-fide employer to a bona-fide employec.

SEC. 4. Prosecutions under this Act shall be commenced only upon the express direction of the Attorney General of the United States.

Sec. 5. If any provisions of this Act or the application thereof to any person or circumstance is held invalid, the remainder of the Act, and the application of such provision to other persons or circumstances, shall not be affected thereby.

Sec. 6. Any person charged with violating this Act may be prosecuted in any district in which any part of the offense has been committed by him or by his actual associates participating with him in the offense or by his fellow conspirators: Provided, That no court of the United States shall construe or apply any of the provisions of this Act in such manner as to impair, diminish, or in any manner affect the rights of bona-fide labor organizations in lawfully carrying out the legitimate objects thereof, as such rights are expressed in existing statutes of the United States. 
one to ten years' imprisonment or by a fine of $\$ 10,000$, or both, to obtain "the payment of money or other valuable considerations or the purchase or rental of property or other prospective services" by the use of, or the threat to use "force, violence, or coercion" when such conduct is "in connection with or in relation to any act in any way or in any degree affecting" interstate or foreign commerce.

The safeguards introduced at the behest of labor are the following: "Money," "property," etc., are defined so as not "to include wages paid by a bona-fide employer to a bona-fide employee." Prosecutions under the Act are to be "commenced only upon the express direction of the Attorney General of the United States."7 A proviso forbids the construction or application of the Act "in such manner as to impair, diminish, or in any manner affect the rights of bona-fide labor organizations in lawfully carrying out the legitimate objects thereof, as such rights are expressed in existing statutes of the United States."8

The Act has the commerce clause for its constitutional basis, yet, as has been pointed out, the activities of racketeers are primarily local. Therein lies an explanation for the breadth of the clause which seeks to bring within the scope of the Act racketeering "in connection with or in relation to any act in any way or in any degree affecting" interstate or foreign commerce. ${ }^{9}$ The italicized words must be contrasted with the insistence heretofore evident in the opinions of the Supreme Court that only such intra-state activities come within the commerce power of Congress as operate to obstruct or burden interstate commerce "directly,"10 "substantially,"11 or "unduly," 12 to select but three of the most commonly employed restrictive adverbs.

So far as prosecutions against racketeering activities are based on conduct which may be found to fall within the scope delimited by the pragmatic judgments which such terms imply, ${ }^{13}$ there seems no question but that the Act does not go beyond the bounds of federal power. But where the prosecution is directed at the acts of a single wrongdoer, and not at the activities of a combination, it may be difficult to establish that his conduct has more than an "incidental" effect upon interstate commerce. Perhaps, in such a case, the federal courts will expressly abandon the restrictions in their current doctrine or, preserving the formula, will relax its inhibitions by a liberal construction. Whether this will be done is a question as to which, in the absence of actual situations, even an effort at prediction would be futile.

- Anti-Racketeering Act, $\S_{3}$ (b). See also ibid. $\$_{2}$ (a).

${ }^{7}$ Ibid. \$4. ${ }^{8}$ Ibid. \$6. ${ }^{0}$ Ibid. \$2.

${ }^{10}$ See, e. g., Anderson v. U. S., 17x U. S. 604, 615, 19 Sup. Ct. 50, 54 (1898); Chicago Board of Trade v. Olsen, 262 U. S. I, 40, 43 Sup. Ct. 470,478 (1923).

${ }^{11}$ See, e. g., Bedford Cut Stone Co. v. Journeyman Stone Cutters' Ass'n., 274 U. S. 37, 54, 47 Sup. Ct. 522, 527; Local r67, etc. v. U. S., 29I U. S. 293, 297, 54 Sup. Ct. 396, 398 (1934).

${ }^{12}$ See, e. g., Stafford v. Wallace, 258 U. S. 495, 521, 42 Sup. Ct. 397,403 (1922).

23 "The distinction between the direct and indirect effects (upon interstate commerce) of a combination is necessarily practical rather than ratiocinative. It is impossible to draw a line which shall be immune from casuistical attack, and perhaps it is unfortunate that the somewhat arbitrary and pragmatic nature of what courts do in such cases has been so frequently disguised by a show of deduction." Learned Hand, J., in Live Poultry Dealers' etc. Ass'n v. U. S., 4 F. (2d) 840,842 (C. C. A. 2d, 1924). 
The Bank Robbery Act

Unlike many of the offenses at which the recent federal legislation is directed, bank robberies are localized crimes. But the apprehension of the bank robbers is, on the other hand, a task which requires the coördinated efforts of law enforcement agencies over wide territories. The automobile, in increasing the mobility of criminals, has placed a strain on our parochial police systems that has been felt peculiarly with respect to bank robberies. The value of the loot furnishes an incentive to careful preparation on the part of the criminals. In the Middle West particularly, raids have been made on banks in the smaller communities by bandits who, once having outdistanced pursuit, have retreated to other states for the division of the spoils.

Since only federal forces are free to conduct their operations without regard for state lines, the federal government is in a strategic position to combat such activities. Moreover, its jurisdiction is not circumscribed in this instance by the limits of the commerce power. As to banks organized under federal laws and member banks in the Federal Reserve System, the same constitutional authority which enabled Congress to create federal banking systems ${ }^{14}$ would seem clearly to extend to their protection from felonious attack.

The bank robbery bill introduced by Senator Ashurst on February 2r, I934, ${ }^{15}$ sought to create four federal offenses. The first section limited the Act's application to the types of banks mentioned above. Section 2 made it a felony ${ }^{16}$ to take money or property belonging to or in the possession of a bank either without its consent or with its consent when such consent was induced by fraud. Section 3 penalized ${ }^{17}$ breaking into a bank building with the intent to commit a felony as defined by the laws applicable thereto. Section 4 applied to the forcible taking of bank money or property "from the person or presence of another," providing an increased penalty ${ }^{18}$ where this offense is accompanied by an assault with a dangerous weapon. Section 5 imposed the penalty of a ro-year minimum imprisonment or death on one who in committing an offense under the Act or in seeking to avoid arrest or to escape after arrest should kill any person or force any person to accompany him in his flight. The final section provided that jurisdiction over offenses defined by the Act should "not be reserved exclusively to courts of the United States."

The first two offenses defined in the Senate bill came a cropper in the House Judiciary Committee ${ }^{19}$ whose chairman, Representative Sumners of Texas, sought throughout the session to confine extensions of federal power to those situations

\footnotetext{
${ }^{11}$ The leading case sustaining this power is McCulloch v. Maryland, 4 Wheat. 316 (U. S. 18xg). A more recent case reviewing the earlier decisions is Smith v. Kansas City T. \& T. Co., 255 U. S. 180, $4^{\mathrm{I}}$ Sup. Ct. 243 (1921).

${ }^{15}$ S. $284 x, 73^{\text {rd }}$ Cong., 2nd Sess. (x934).

${ }^{10}$ Punishable by a fine of not more than $\$ 5,000$ or imprisonment for not more than so years, or both.

${ }^{17}$ For the penalty, see note 16 , supra.

${ }^{18}$ For the penalties imposed by this section, see text of Act, infra, note 20.

${ }^{20}$ For the amendments reported by the Committee, see 78 ConG. REc. 8347 (1934).
} 
where the need to supplement state and local law enforcing agencies had become imperative. It is evident that to have brought all cases in which money is taken fraudulently from banks within the scope of federal criminal jurisdiction would have placed a heavy enforcement burden upon the federal government. Moreover, the element of interstate flight is frequently absent from such case. The elimination of Sections 2 and 3 of the Senate bill focussed the measure upon the typical, gangster bank robbery.

The Senate having concurred in the House amendments, the bill was approved on May I8, r934. ${ }^{20}$ Its operation, even in its amended form, will prove an interesting test of the oft-repeated assertion that extensions of federal authority are coupled with a corresponding diminution in state and local effort. ${ }^{20^{3}}$ If such occurs, then it may be questioned whether the legal protection of banks has been materially strengthened by this statute.

\section{THE "KrCK-BACK" ACT}

An evil which has flourished in the period of the depression is the "kick-back." State and federal statutes ${ }^{21}$ provide that labor performed on public buildings and other construction projects shall be paid at the "prevailing rate of wages" for such work. Where union organization is strong, wage rates thus protected have remained during the depression period at higher levels than those prevailing in other lines of work. But pressure has been brought on such rates from two directions. Dishonest contractors submit unduly low bids and having thereby secured contracts seek to recoup by obliging their employees to "kick back" a certain portion of their pay which nominally remains at the prevailing rate. Some of the devices used to effect

${ }^{20} 48$ STAT. 783 , I2 U. S. C. A. (Supp. 1934) $\$ \$ 588 \mathrm{a}-588 \mathrm{~d}$. Its text follows:

An Act to provide punishment for certain offenses committed against banks organized or operating under laws of the United States or any member of the Federal Reserve System.

Be it enacted, etc., That as used in this act the term "bank" includes any member bank of the Federal Reserve System, and any bank, banking association, trust company, savings bank, or other banking institution organized or operating under the laws of the United States.

SEc. 2. (a) Whoever, by force and violence, or by putting in fear, feloniously takes, or feloniously attempts to take, from the person or presence of another any property or money or any other thing of value belonging to, or in the care, custody, control, management, or possession of, any bank shall bc fined not more than $\$ 5,000$ or imprisoned not more than 20 years, or both.

(b) Whoever, in committing, or in attempting to commit, any offense defined in subsection (a) of this section, assaults any person, or puts in jeopardy the life of any person by the use of a dangerous weapon or device, shall be fined not less than \$I,000 nor more than \$I 0,000 or imprisoned not less than 5 years nor more than 25 years, or both.

SEC. 3. Whoever, in committing any offense defined in this act, or in avoiding or attempting to avoid apprehension for the commission of such offense, or in freeing himself or attempting to free himself from arrest or confinement for such offense, kills any person, or forces any person to accompany him without the consent of such person, shall be punished by imprisonment for not less than to years, or by death if the verdict of the jury shall so direct.

SEC. 4. Jurisdiction over any offense defined by this act shall not be reserved exclusively to courts of the United States.

zosa The risk that this may occur is termed a "serious danger" by Dr. Raymond Moley in his Report to the President on Federal Enforcement of Criminal Law. N. X. Times, May 24, I934, P. 2.

${ }^{21}$ For the federal statute, see 45 STAT. 1494 (193I), 40 U. S. C. A. (Supp. I933) $\$ 276$ a. 
the "kick-back" are described in a note. ${ }^{22}$ Unscrupulous labor union officials also take advantage of the situation of members long unemployed by exacting tribute from them as a condition to their employment. Usually such payments are made under color of union authorization. ${ }^{23}$

The disclosure that the "kick back" was operative on federal building projects led to the introduction of a bill on March 12, $1934^{24}$ which provides the penalty of a maximum fine of $\$ 5,000$ or imprisonment up to 5 years where one person induces another who is employed in the construction of "any public building, public work, or building or work financed in whole or in part by loans or grants from the United States" to give up any part of the compensation to which he is entitled "by force, intimidation, threat of procuring such dismissal, or by any manner whatsoever." A second section empowers the Secretaries of the Treasury and the Interior to make reasonable regulations to this end for contractors and subcontractors, including a provision for sworn weekly affidavits as to the wages paid their employees. The bill became law June $13,1934 \cdot{ }^{25}$

22 "How the 'kick-back' works is almost common knowledge in the building trades. In other instances they were paid the prevailing rate of wages, but they have to kick back a percentage of their pay following pay day or they cannot return to work on the job. Many are sold tickets for shore dinners that never take place. Men are forced to join social clubs where they must pay a high rate of ducs with little or no socialibility in return. Another form of the racket is worked by taking moncy out of the pay envelop and giving the man a receipt to show he is purchasing stock on the installment plan in some defunct corporation. I heard of one case in which a foreman would not hire anyone who did not live in a boarding house where the foreman rented rooms at an exorbitant rate. In another casc a man pawned his wife's wedding ring to buy a job. Having given the money to the wrong man he did not receive the job."

Statement of G. J. Atwcll, President, Atwell Foundation Corporation, Hearings pursuant to S. Res. 74, 73rd Cong., 2nd Sess., Vol. I, pt. 5, p. 797 (Dec. 21, 1933).

${ }^{23}$ See Letter by H. W. Ameli, U. S. Atty., Eastern District, N. Y., ibid. p. 826.

${ }^{24}$ S. 304 I, 73rd Cong., 2nd Sess. (1934).

$\approx$ Public, No. 324, 73rd Cong., 2nd Sess. (1934), 40 U. S. C. A. (Supp. 1934) $\$ 276 b-276 c$. Its text follows:

An Act to effectuate the purpose of certain statutes concerning rates of pay for labor, by making it unlawful to prevent anyone from receiving the compensation contracted for thereunder, and for other purposes.

Be it enacted, etc., That whoever shall induce any person employed in the construction, prosecution, or completion of any public building, public work, or building or work financed in whole or in part by loans or grants from the United States, or in the repair thereof to give up any part of the compensation to which he is entitled under his contract of employment, by force, intimidation, threat of procuring dismissal from such employment, or by any other manner whatsoever, shall be fined not more than $\$ 5,000$, or imprisoned not more than 5 years, or both.

SEC. 2. To aid in the enforcement of the above section, the Secretary of the Treasury and the Secretary of the Interior jointly shall make reasonable regulations for contractors or subcontractors on any such building or work, including a provision that each contractor and subcontractor shall furnish wcekly sworn affidavit with respect to the wages paid each employee during the preceding week. 